\title{
A Cytochemical Investigation on the Sweat Glands of the Monkey
}

\author{
By \\ Shinji Matsumoto, Masanobu Yoshida and Umeo Tateno \\ Department of Anatomy, School of Medicine, Keio University, Tokyo, Japan \\ (Director: Prof. Dr. T. Taniguchi)
}

\section{Introduction}

It is said that the first stage of the investigation on the sweat glands has been completed by $\mathrm{Sch}$ iefferdicker (1922). Recently I t o (1949) on "the histology and cytology of the sweat glands" and also Taniguchi (1956) on "the sweat glands of man and mammals (Die Schweissdrüse des Menschen und der Säugetiere, mit besonderer Berücksichtigung ihrer quantitativen Verbreitung) have respectively published their detailed findings with reference to their joint works. Furthermore, many scientists have made morphological investigations on sweat glands of man and various animals from many sided view points. On the contrary, with the progress of the study by means of histochemical methods, these methods are applied to various sides of medical science. But, not any histochemical investigation on the sweat glands of the monkey have been yet encountered. In the present investigation, several findings on the sweat glands of the monkey by means of histochemical methods obtained by us shall be reported in this paper.

\section{Material and Methods}

A female monkey (Macaca fuscata fuscata) of one year of age was employed as material in the present investigation. Pieces of the fresh skin taken from the monkey under ether anesthesia were stained by following methods. 
1. The sections fixed with cold acetone solution were stained by the Gomori's method (1952) for detection of the alkaline phosphatase and were treated with the Gomori 's method (1953( for the demonstration of lipase.

2. The sections fixed with alcohol were stained by the PAS method for the demonstration of glycogen and were examined by $\mathrm{P}$ erls-Stieda's method, that is, Berline blue reactive method $(1867,1893)$ for iron.

3. The sections fixed with formalin solution were treated with the $\mathrm{Hg}$-BPB method for detection of protein and also were stained with hematoxylin-eosin staining for general observations.

Pieces of the skin were taken from the facial region (forehead and nasal wings), the upper extremity (extensor and flexor sides) and the palm (hairy transitional region of the palm and the palm itself). These were sectioned serially at $5 \mu$ and observed from histologically and histochemically.

\section{Original Findings}

1. Apocrine sweat gland. In the authors' material, the apocrine sweat glands are noticed in the forehead, in the extensor and flexor sides of the upper extremity and in a portion of the hairy transitional region of the palm but not in the palm itself. The excretory ducts open their orifices into the hair follicles above the orifice of the excretory duct of the sebaceous gland, and the ducts running down winding a little at the obtuse angled side of the hair follicle migrate to the glandular ducts locating in the subcutaneous adipose tissue at the deeper portion below the sebaceous gland. Contrary to the eccrine sweat glands forming glomerular shape, the apocrine sweat glands chiefly show a fundiform shape, not glomerular shape.

At the hairy region of the palm, the apocrine sweat glands are seen to be more numerous than the eccrine sweat glands. The duct of the apocrine sweat gland is much larger than that of the eccrine sweat gland. Accordingly the ductular lumen of the former is also larger than that of the latter. Sometimes a desquamated substance like the glandular cell's is noticeable in the lumen. The shape of the glandular cells is so various as cuboidal, flat and columnar that it is hard to differentiate the form of the cell in one region from that in other regions. Comparatively large and dark cells stained with hematoxylin-eosin are observed forming a layer 
systematically. The nucleus which is round or elliptic is stained deep with hematoxylin-eosin and comparatively large in size. The nucleus is maldistributed in the cell, which has only one nucleus but not two or more. At the base of the glandular cell, the transversal side of the arrangement in the spindle shaped nucleus of the cell of the smooth muscle forms one layer. The cytoplasm is not clearly noticeable. The cells of the excretory duct show a cuboidal form and are arranged in one or two layers.

2. Eccrine sweat gland. In the authors' material, the eccrine sweat glands are chiefly recognizable in the palm and a little in the forehead, in the nasal wings and in the extensor and flexor sides of the upper extremity, but in the hairy transitional region of the palm the eccrine sweat glands are found numerously in some sections and found a little in other sections, accordingly in this region the number of the eccrine sweat glands is medium. The excretory ducts run down curving a little from the sudoriferous opening and pass into the glandular ducts at the deep layer of the derm. The glandular ducts show a perfect glomerular formation, especially in the palm. This formation is observed more often in the palm than in the hairy region of the palm. The glandular cells of the glandular duct which are small and show irregular form, are unsystematically arranged in one or two layers. The portion that faces the lumen is also irregular.

In the staining condition with hematoxylin-eosin, not any remarkable differences are observed in the cells at the basement and those in the superficial region. The lumen of the eccrine sweat gland is narrower than that of the apocrine sweat gland but the desquamated substance like the glandular cell's is found in the lumen as well as in the apocrine sweat gland. The nucleus is small and generally locates at the central portion of the cell of the gland but infinitive. At the base of the glandular cells, the spindle shaped nuclei of the smooth muscle cells lying transverse are recognized as forming one layer.

\section{Alkaline phosphatase}

1) Forehead.

a) Apocrine sweat gland (Fig. 1).

Glandular duct: In the glandular ducts at the part that faces the cavity of the glandular cells, show an extremely intensive and membranous activity. In the cytoplasm a small, and weakly granular 
activity is diffusely found, and the intensity of the activity is the same at both portions above and below the nucleus. In the karyoplasm as well as in the cytoplasm a weak granular activity is found. At the base of the cell a zonal activity of medium intensity is observed adjacent to the myoepithelial cells. In the boundary region between the cells the activity is very weak, and sometimes a tubular, unstainable and tranparent portion is observed. In the myoepithelial cells, the activity is most intensive after the region that faces the lumen of the glandular cell.

Excretory duct. At the portion that faces the cellular cavity, which is adjacent to the ductular lumen, the activity is not generally found, but faint filamentous and intermittent weak activity is observed on rare occasions. No activity is found in either cytoplasm or karyoplasm. Moreover, no activity is found in the portion between the cells of the outer and inner layers.

b) Eccrine sweat gland (Fig. 2).

Glandular duct. Though the activity of medium intensity is found at the region that faces the cavity of the glandular cell, the activity is not found in the general cell. Namely the activity is intermittent and weak. In the cytoplasm of the cells of the superficial layer the activity at the portion above the nucleus does not differ essentially from that at the portion below the nucleus, and at both portions a small granular, and weak activity is diffusely observed. The activity in the cytoplasm of the cells at the base is weak but it is more intensive than that in the superficial cells. In the karyoplasm weak and granular activity is observed. Particularly at the boundary portion between the cells no activity is found. Very intensive activity is recognized in the myoepithelial cells.

Excretory duct. Not only in the cells and karyoplasm but in the portion between the cells in the inner and outer layers no activity is observed.

As for a remarkable difference in the activity between the apocrine sweat glands and the eccrine sweat glands, at the portion that faces the cell cavity, the former shows a particularly intensive and membranous activity but the latter does medium and intermittent. Furthermore, at the base of the cells and in the myoepithelial cells in the apocrine sweat glands the activity is of medium intensity, on the other hand in the eccrine sweat glands it is very intensive. 
2) Nasal wing.

a) Apocrine sweat gland (Fig. 3).

Glandular duct. In the glandular duct some portion that faces the cavity of the glandular cells exhibits an intensive activity but others do not, or do intermittent activity. Small granular and weak activity is observable diffusely in the cytoplasm. In the karyoplasm, granular and weak activity is found. At the boundary portion between the cells no activity is recognized. The base of the cells shows an intensive activity. Particularly intensive activity is found in the myoepithelial cells.

Excretory duct. In the excretory ducts, not any activity is observed in the whole cell, nor in the portion between the cells.

b) Eccrine sweat gland (Fig. 4).

Glandular duct. In the glandular ducts, at the portion that faces the cavity of the glandular cells the arrangement of the cells with the activity of medium intensity is sparsely observed. The cytoplasm shows a very weak activity. The cells at the base show stronger activity than the cells in the superficial layer does. In the karyoplasm a weak activity is found. A medium activity is recognized in the myoepithelial cells and at the base of the cells.

Excretory duct. In the excretory duct, every part of the cell and the portion between the cells of the inner and also the outer layers do not show any enzymatic activity.

As for a noticeable difference in the activity between the apocrine sweat glands and the eccrine sweat glands, the former shows an intensive activity at the portion that faces the cell cavity but the latter presents a medium one, besides the former exhibits a strong activity that can be seen at the base of the cells and in the myoepithelial cells, but the latter shows a medium one.

3) Extensor side of the upper extremity.

a) Apocrine sweat gland (Fig. 5).

Glandular duct. In the glndular ducts, the activity of medium intensity is membranously observed at the portion that faces the cavity of the glandular cells. In the cytoplasm the granular weak activity is diffusely recognized. There is no difference in the activity between the portions above and below the nucleus. In the karyoplasm a weak and granular activity is found. At the boundary portion between the cells, activity is not particularly observed. However, a picture like the tubule is sometimes encountered. The activity at the base of the cell is of medium intensity. Similarly in the 
myoepithelial cells the activity is of medium intensity.

Excretory duct. In the excretory ducts, every part of the cell and the portion between cells of the inner and outer layers never show any activity.

b) Eccrine sweat gland (Fig. 6).

Glandular duct. In the glandular duct, a weak activity is noticed at the portion that faces the cavity of the glandular cells. Very weak activity is diffusely found in the cytoplasm. Though the activity in the superficial cells is somewhat intensive, it is weak in the basement cells. A weak activity is found in the karyoplasm. The myoepithelial cells show a medium activity.

Excretory duct. Not any activity is recognizable at the portion between the cells of the inner and outer layers nor in any other part of the cell.

Thereupon, as for a remarkable difference in the activity between the apocrine and the eccrine sweat glands, the former shows a medium activity at the portion that faces the cavity while the latter shows a weak one.

4) Flexor side of the upper extremity.

a) Apocrine sweat gland (Fig. 7).

Glandular duct. In the glandular ducts, at the part that faces the cavity of the glandular cells a medium activity in the membranous structure is recognized. In the cytoplasm a weak and granular activity is diffusely noticed. In the karyoplasm too, a weak and diffusely granular activity is found. Namely, the activity in both the cytoplasm and karyoplasm is weak. At the boundary portion between the cells not any specific activity is noticeable. The base of the cells and the myoepithelial cells exhibit a medium activity.

Excretory duct. Every part of the cell and also the portion between the cells of the inner and outer layers never show any activity.

b) Eccrine sweat gland (Fig. 8).

Glandular duct. In the glandular duct, very faint activity is noticeable at the part that faces the cavity of the glandular cells. The activity in the cytoplasm is also very weak. The activity in the superficial cells is less intensive as compared with that in the basement cells. The karyoplasm shows a faint activity, while the myoepithelial cells show a medium activity.

Excretory duct. Not any activity is noticeable at the every portion of the cell and even at the portion between the cells of the 
inner and outer layers.

Thereupon, as for a remarkable difference in the activity betwecn the apocrine and the eccrine sweat glands, the former shows a medium activity at the portion that faces the cavity, while the latter does a very weak one. This finding is similar to that obtained from the observation of the previous extensor side of the upper extremity.

5) Hairy transitional region of the palm.

a) Apocrine sweat gland.

No apocrine sweat glands are found in the authors' material.

b) Eccrine sweat gland (Fig. 9).

Glandular duct. In the glandular ducts, the activity at the portion that faces the cavity of the glandular cells is weak or the same as that in the cytoplasm. In the cells in the superficial layer, a very weak and granular activity is noticed chiefly at the portion above the nucleus, but at the same time, the considerablly larger part of the cytoplasm does not show activity at all. In the cell at the base very faint activity is chiefly demonstrated at the portion around the nucleus, on the other hand, the portion showing no activity is also found. In the karyoplasm a weak activity is recognized. Between the cells a portion showing a tubular feature is observed, but not any specific activity is noticed. In the myoepithelial cells an intensive activity is perceptible.

Excretory duct. In the excretory ducts, no activity is observed at any portion of the cell, nor even at the portion between the cells of the inner and outer layers.

6) Palm.

a) Apocrine sweat gland.

In the authors' material, not any apocrine sweat glands are found in this region.

b) Eccrine sweat gland (Fig. 10).

Glandular duct. In the glandular ducts a weak or very faint activity is observed at the portion that faces the cavity of the glandular cells. In the cytoplasm of the superficial cells a weak activity is chiefly recognized at the portion above the nucleus. In the cytoplasm of the basement cells a weak activity is observed around the nucleus, at the same time there are seen some portions in the cytoplasm where no activity is observed. Though a portion showing a tubular image is observable at the boundary portion between each cell, no specific activity is recognized. In the karyoplasm the activity of medium intensity is noticed. Very intensive activity is observed 
in the myoepithelial cells.

Excretory duct. In the excretory ducts not any activity is observed at the portion of the cell and even at the portion between the cells of the inner and outer layers.

\section{Lipase}

1) Forehead (Figs. 11 and 12).

2) Nasal wing (Fig. 13).

3) Extensor side of the upper extremity (Figs. 14 and 15).

4) Flexsor side of the upper extremity (Figs. 16 and 17).

5) Hairy transitional region of the palm (Fig. 18).

6) Palm.

At the regions mentioned above, the activity of lipase is never observable not only in the cytoplasm and karyoplasm of the glandular duct but also in the portion that faces the cavity of the glandular cells, in the myoepithelial cells and at the base of the cells in both the apocrine and eccrine sweat glands.

Similarly, in the excretory ducts at these regions, the activity is not observed at every portion.

\section{Glycogen (PAS staining)}

1) Forehead (Figs. 20 and 21).

2) Nasal wing.

3) Extensor side of the upper extremity (Figs. 22 and 23).

4) Flexor side of the upper extremity (Fig. 24).

5) Hairy transitional region of the palm (Fig. 25).

a) Apocrine sweat glands at the regions mentioned above.

Glandular duct. The PAS stainable substance is not found at any portion of the cytoplasm of the glandular cells. That is, not any specific findings are recognizable at the portion that faces the cavity of the cells, the surroundings of the nucleus and the base of the cells. Furthermore, not in every portion of the karyoplasm and of the myoepithelial cell, is a PAS stainable substance found.

Excretory ducts at the five regions. No PAS stainable substance is observed in each part in the excretory duct.

b) Eccrine sweat glands at the five regions.

Glandular duct. In the glandular ducts, at the portion that faces the cavity of the glandular cells, a weak and granular PAS stainable 
substance is observed. In the cytoplasm of the superficial cells a very faint and granular PAS stainable substance is recognizable. At the base of the cells a weak and granular PAS stainable substance is noticed. In every case, PAS stainable substance is found profusely, and sometimes it is found in groups, especially around the nucleus. In the karyoplasm no PAS stainable substance is observed. At the base of the cells and in the myoepithelial cells a weak stainable PAS substance is recognized.

Excretory duct. In no parts of the excretory duct is any PAS stainable substance noticeable.

6) Palm (Fig. 26).

a) Apocrine sweat gland.

In the authors' material the apocrine sweat glands are not found at this region.

b) Eccrine sweat gland (Fig. 10).

Glandular duct. In the glandular ducts the portion that faces the cavity of the glandular cells has weak and granular PAS stainable substance. In the cells at the base, weak and granular PAS stainable substance is profusely observed. There is no difference in the stainability between the portions above and below the nucleus. At the tubular portion between the cells, not any specific changes in the stainability are observed. No PAS stainable substance is recognized in the karyoplasm, while in the myoepithelial cells and at the base of the cells a weak stainable PAS substance is observed.

Excretory duct. The PAS stainable substance is not found at any portions in the excretory ducts.

\section{Iron.}

1) Forehead (Fig. 27).

2) Nasal wing (Fig. 28).

3) Extensor side of the upper extremity (Figs. 29 and 30).

4) Flexor side of the upper extremity (Figs. 31 and 32).

5) Hairy transitional region of the palm (Figs. 33 and 34). On the regions mentioned above:

a) Apocrine sweat gland.

In the glandular duct, no iron stainability is observed in the cytoplasm, karyoplasm and myoepithelial cells.

In the excretory duct, stainability is not found in every where.

b) Eccrine sweat gland. 
In the glandular duct, no iron stainability is noticed in the cytoplasm, karyoplasm and myoepithelial cells.

In the excretory duct, similarly, no iron stainability is observed.

6) Palm (Fig. 35).

a) Apocrine sweat gland.

In the authors' material, no apocrine sweat glands are observed.

b) Eccrine sweat gland.

Glandular duct. In the glandular duct, none of the cytoplasm, karyoplasm, and myoepithelial cells show the iron stainability.

Between the cells of the superficial layer and at the base, there is no difference in the stainability, besides no stainability is found anywhere else either.

Excretory duct. The stainability for iron is not observed in any parts of the cell.

\section{Protein (Hg-BPB staining method)}

1) Forehead.

a) Apocrine sweat gland (Fig. 36).

Glandular duct. In the glandular ducts, the portion that faces the cavity of the glandular cells shows an intensive and membranous stainability. The cytoplasm, without any difference in the stainability between the portions above and below the nucleus, gives a medium and diffuse stainability. In the karyoplasm, as well as in the cytoplasm, a medium stainability is observed. Between the cells a weak and tubular stainability is recognized. At the base of the cells and in the myoepithelial cells very intensive stainability is seen.

Excretory duct. A weak stainability is observed in the general cells in the excretory duct.

b) Eccrine sweat gland (Fig. 37).

Glandular duct. In the superficial cells particularly intensive stainability is found at the portion that faces the cell cavity. Furthermore in the cytoplasm and karyoplasm the stainability is of medium intensity.

As compared with the superficial cells, the basal cells show a weaker stainability both in the cytoplasm and karyoplasm. On the other hand, the myoepithelial cells show an intensive stainability.

Excretory duct. A weak stainability can be seen all over the cell in the excretory ducts.

2) Nasal wing. 
In the authors' material, both the apocrine and eccrine sweat glands are never found.

3) Extensor side of the upper extremity.

a) Apocrine sweat glands (Fig. 38).

Glandular duct. The cytoplasm in the glandular ducts shows a profuse and medium stainability. At the portion that faces the cavity of the glandular cells, somewhat intensive stainability of the membranous side is observed. In the karyoplasm a medium stainability is recognized. At the base of the cells and in the myoepithelial cells very intensive stainability is noticeable.

Excretory duct. All over the cells in the excretory ducts somewhat weak stainability is seen.

b) Eccrine sweat gland (Fig. 39).

Glandular duct. In the cytoplasm of the superficial cells in the glandular ducts, the stainability is of medium intensity. The portion facing the cavity of the glandular cells shows extremely intensive stainability and the karyoplasm shows a medium stainability. In the cytoplasm and karyoplasm of the basal cells, a weak stainability is observed. While in the myoepithelial cells, an intensive stainability is found.

Excretory duct. A weak stainability is met with in all the cells in the excretory ducts.

4) Flexor side of the upper extremity.

a) Apocrine sweat gland (Fig. 40).

Glandular duct. In the cytoplasm of the cells in the glandular ducts a stainability of medium intensity is widely observed, while in the portion that faces the cavity of the glandular cells an intensive stainability is recognizable. The karyoplasm shows a medium stainability. At the base of the cells and in the myoepithelial cells an intensive stainability is observed.

Excretory duct. All over the cells in the excretory ducts, generally, a weak stainability is met with.

b) Eccrine sweat gland (Fig. 41).

Glandular duct. In the superficial cells in the glandular ducts, the cytoplasm and karyoplasm show a weak stainability. On the other hand, the stainability at the portion that faces the cavity of the glandular cells is of medium intensity. In the basal cells the cytoplasm and karyoplasm show very faint stainability. While in the myoepithelial cells an intensive stainability is observed.

Excretory duct. All over the cells in the excretory ducts, gener- 
ally, a weak stainability is observed.

5) Hairy transitional region of the palm.

a) Apocrine sweat gland (Fig. 42).

Glandular duct. At the portion that faces the cavity of the glandular cells a membranous and medium stainability is observed. In the cytoplasm and karyoplasm a weak stainability is seen to be diffuse. An intensive stainability is met with in the myoepithelial cells and at the base of the cells.

Excretory duct. A weak stainability is observed all over the cells.

b) Eccrine sweat gland (Fig. 43).

Glandular duct. In the superficial cells the cytoplasm and karyoplasm show a weak stainability. While at the portion that faces the cavity of the glandular cells the stainability is of medium intensity. In the basal cells, cytoplasm and karyoplasm have a faint stainability. On the other hand, very intensive stainability is observed in the myoepithelial cells.

Excretory duct. General weak stainability is observed all over the cells in the excretory ducts.

6) Palm.

a) Apocrine sweat gland.

In the authors' material, not any apocrine sweat glands are found in this region.

b) Eccrine sweat gland (Fig. 44).

Glandular duct. A weak stainability is observed in the cytoplasm and karyoplasm in the superficial cells. The stainability at the portion that faces the glandular cells is weak, whereas it intensive at that portion in the hairy transitional region of the palm. The cytoplasm and karyoplasm in the basal cells show a faint stain ability. In the myoepithelial cells very intensive stainability is noticed.

Excretory duct. General weak stainability is observed all over the cells in the excretory ducts.

\section{Discussions}

Histological and cytological investigations on the sweat glands of man and animals have been made for long by many scholars. Furthermore, recently these have been examined from the histo- and cytochemical view-points.

Observing the sweat glands in the female monkey (Macaca fuscata fuscata) of one year of age without any treatment, the authors 
obtained the findings as mentioned already, by means of cytochemical methods.

1) Concerning the alkaline phosphatase in the sweat glands, it is well understood that the myoepithelial cells and the epithelium of secretory region of the gland have very intensive activity. Mo nt a g $\mathrm{n}$ a (1956) has observed a medium activity in the apocrine sweat glands at the human axilla, besides he has found partially a strong activity at the base of the cells and in the myoepithelial cells. Accordingly, he gives warning that the partial observation may bring a wrong result. On the other hand, he has observed a weak activity in the eccrine sweat glands, though the intensity of the activity depends upon the freshness at the time when the material was fixed. In the myoepithelial cells and in the clear cells a considerable intensive activity is found and in the dark cells a weak activity is observed. However, in the excretory ducts in both the apocrine and eccrine sweat glands no activity is observed.

B unting et al (1948) have observed a weak activity in the epithelium, myoepithelial cells, basal membrane of the secretory region and the portion adjacent to the capillaries in both the apocrine and eccrine sweat glands.

According to $\mathrm{K}$ a g a's report (1956) on the auricular glands of man and several animals, an intensive activity is observed particularly in the cells facing the lumen. In the cytoplasm the activity is of medium intensity and in the karyoplasm it is strong.

In the untreated monkey, examined by the authors, the eccrine sweat glands show more intensive activity as compared with the apocrine sweat glands. Furthermore, in the apocrine sweat glands, an intensive activity is noticed at the portion that faces the cavity of the glandular cells and in the myoepithelial cells. On the contrary, in the cytoplasm and the karyoplasm a weak and granular activity is widely observed. In the eccrine sweat glands, the myoepithelial cells and the basement of the glandular cells show extremely intensive activity. The cytoplasm of the basal cells shows a weak activity, while the cytoplasm of the superficial cells show a very faint activity. In the karyoplasm the activity is weak. In the eccrine sweat glands in the hairy region of the palm, weak or medium activity is observed at the portion that faces the cavity of the glandular cells, while in the palm the activity is weak or very faint. In the excretory ducts of both the apocrine and eccrine sweat glands not any activity is recognizable. 
2) Concerning the detection of the lipase in the sweat glands, $\mathrm{K}$ a g a (1956) reported, that the activity was negative in the auricular glands of man and several animals, when Gomori's method was used. In the authors' untreated monkey, using Go mori 's method, no activity is found in the glandular and excretory ducts of both the apocrine and eccrine sweat glands.

3) Regarding the detection of glycogen in the sweat glands a great number of reports have been published. Bunting et al (1948) observed glycogen in the eccrine sweat glands but did not in the apocrine sweat glands. According to I to's report (1949) on histology and cytology of the sweat glands, glycogen is not contained in the human apocrine sweat glands, while it is contained only in the basal cell in the eccrine sweat glands but in the superficial cell it is not contained. From these facts it is possible to distinguish one cell from another cell, according to glycogen content.

On the other hand, according to $\mathrm{T}$ s u ka g o s h i (1951), glycogen is contained in the eccrine sweat glands of some animals, but not contained in those of other animals, besides the glycogen content varies in its quantity and the cells are located in various positions, differing from such a regular picture as in man, where glycogen is found in the superficial cells, but not in the basal cells.

According to $\mathrm{Ka}$ m a m u ra's investigation (1957) on the eccrine sweat glands of the cat, he denies the theory, that it was possible to decide the kind of the cell judging from the existence of glycogen in the cell.

M o n t a g n a (1956) has insisted, that the apocrine sweat glands in the human axilla do not contain glycogen but the eccrine sweat glands in the same region contain a good deal of glycogen, besides the clear cells generally contain more quantity of glycogen than the dark cells do, and glycogen is observed in the intracellular portion of the clear cell and in the intracellular canaliculi.

Most of the investigators support the assertion, that glycogen is contained in the eccrine sweat glands but not in the apocrine sweat glands. However, some scholars, not a few, assert the existence of glycogen even in the apocrine sweat glands ( $\mathrm{Y} \mathrm{u} \mathrm{g} \mathrm{a} \mathrm{w} \mathrm{a,} \mathrm{1935,} \mathrm{M} \mathrm{i-}$ n a mita $n$ i, 1940).

On the other hand, these points in dispute have been scrutinized under various conditions. Namely, Mi n a m it a n i (1940) has seen glycogen in the apocrine sweat gland in the axillary region and $\mathrm{Nagam}$ itsu (1941) observing the two groups of men who have 
an axillary fetor and those who have not, has not found any difference in the two groups of men where glycogen is negative in the apocrine sweat glands and positive in the eccrine sweat glands. I m a g a w a (1936) has found a great deal of glycogen in the eccrine sweat glands of a diabetic corpse, and he has asserted that glycogen is more contained in the cells in the inner layer of the excretory duct than in those in the outer layer. I to and I w a s h i g e (1953), examining the person of advanced age from the secretory functional point of view, have reported that even in the aged, glycogen is not contained in the apocrine sweat glands. Tsuchiya (1954) has detected glycogen in the sweat glands of human embryos following embryonal months. Y u y ma (1935), who payed his attention to seasonal secretory function, has reported, that glycogen is not contained in the summer when the secretory function is in high condition, on the contrary it is contained in large quantities in the winter, spring and autumn when the perspiration is little.

Considering the above mentioned various assertions, one assertion is denied by the others, so that it is impossible to give a final decision regarding this problem. In the authors' observation on glycogen (by the PAS staining method) in the sweat glands of the untreated monkey, no stainability is found in the apocrine sweat glands, but in the eccrine sweat glands the portion facing the cavity of the glandular cells shows a weak stainability and the cytoplasm of the superficial cells is also weak in stainability and that of the basal cells is diffusely weak. Furthermore, in the hairy regions the stainability is found closely packed. Not any stainability is met with in the karyoplasm. At the basement of the cells and in the myoepithelial cells a weak stainability is observed.

4) Regarding the detection of iron stainability in the human sweat glands, Montag na (1956) has clearly recognized the jron stainability in the apocrine sweat glands, at the same time he has reported, that the dissimilarity in the iron stainability is found even in the same section or specimen and is not found in the excretory ducts. B u n ting (1948) also has recognized the localization of the iron stainability in the apocrine sweat glands. Moreover, according to Mori y a ma (1927) and $\mathrm{Nagamitsu}$ 's (1941) reports on the apocrine sweat glands of the axilla in Japanese, the iron stainability is positive in man possessed with axillary fetor and is negative in man who possesses no axillary fetor. According to I w a s h i g e (1951), in the aged possess axillary fetor, the iron reaction is gradually 
decreased with the decrease in axillary fetor. Everyone denies the existence of the iron stainability in the eccrine sweat glands.

In the authors' observation on the sweat glands of untreated monkey, not any jron stainability is recognized.

5) Regarding the stainability of protein in the sweat glands, Montagna (1956) has reported, that the stainability of protein is very intensive at the portion facing the cavity of the glandular cell and it is gradually decreased towards the base. K a g a (1956), on the auricular glands of several animals, has observed very intensive stainability at the cavity of the cytoplasm.

In the authors' observation on protein ( $\mathrm{Hg}$-BPB method) in the sweat glands of the untreated monkey, in the apocrine sweat glands the portion facing the cavity of the glanduiar cells shows very intensive stainability, but the cytoplasm and karyoplasm show a medium stainability. At the base the myoepithelial cells show an intensive stainability. On the other hand, in the eccrine sweat glands, the portion facing the cavity of the glandular cells shows intensive or medium stainability in the hairy transitional region of the palm, while in the palm itself that portion shows a weak stainability. As for the cytoplasm and karyoplasm, those in the superficial cells are of weak stainability and those in the basal cells are of very faint stainability. In the inyoepithelial cells and at the base of the cells very intensive stainability is seen.

\section{Summary}

The authors examined the sweat glands in the facial region, the upper extremity and the palm from the cytological and cytochemical view-points, and obtained the following conclusions.

1) On the activity of alkaline phosphatase: In the apocrine sweat glandular duct the activity is intensive at the portion that faces the cavity of the glandular cells. The activity gets weak in order of the myoepithelial cells, karyoplasm and cytoplasm. In the eccrine sweat glandular ducts, the activity is extremely intensive at the base of the glandular cells, and in order of the portion that faces the cavity of the glandular cells, karyoplasm, cytoplasm of the basal cell and cytoplasm of the superficial cell, the activity is weak. In conclusion, as for noticeable differences in the activity between the apocrine and eccrine sweat glands, the portion that faces the cavity of the glandular cells, the base of the cells and the 
myoepithelial cells attract special attention. Moreover, the portion that faces the cavity of the glandular cells in the eccrine sweat glandular ducts in the hairy transitional region of the palm shows a medium activity, on the other hand that portion in the eccrine sweat glandular ducts in the palm shows a weak activity. Not any activity is observed in the excretory ducts of the apocrine and eccrine sweat glands.

2) On the activity of lipase, not any activity is found in the glandular and excretory ducts of the apocrine and eccrine sweat glands.

3) On the stainability of glycogen by means of PAS staining methoa. Not any PAS stainable substance is seen in the glandular and excretory ducts of the apocrine sweat glands. However, in the glandular ducts in the eccrine sweat gland a weak stainability, at the portion that faces the cavity of the glandular cells and in the myoepithelial cells, is observed. In the cytoplasm of the basal cells the stainability is weak and in the cytoplasm of the superficial cells the stainability is very faint. In the cytoplasm in the palm the stainability is seen scattered, and though in the cytoplasm in the hairy transitional region of the palm it is seen scattered, it is sometimes observed packed arround the nucleus. In the excretory ducts of both the apocrine and eccrine sweat glands, not any PAS stainable substance is observed.

4) On the iron stainability ( $\mathrm{Hg}-\mathrm{BPB}$ method). Not any stainability is observed in the glandular and excretory ducts of both the apocrine and eccrine sweat glands in every examined region.

5) On the protein stainability by means of the Hg-BPB method. In the apocrine sweat glands, the stainability is intensive in the myoepithelial cells, and weak in the portion that faces the cavity of the glandular cells, the karyoplasm and the cytoplasm in that order. In the eccrine sweat glands, an intensive stainability is observed in the myoepithelial cells. In both the cytoplasm and karyoplasm the stainability is weak, and those are still weaker in stainability in the basal cells than in the superficial cells. In the portion that faces the cavity of the glandular cells, the stainability is less intensive in the palm than in the hairy transitional region of the palm. In the excretory ducts of both the apocrine and eccrine sweat glands, general weak stainability is observed all over the cells.

The authors wish to acknowledge their indebtness to Prof. Dr. T. Taniguchi for his valuable criticism and to Instructor Dr. $\mathrm{K}$. Y a $\mathrm{s} \mathrm{u}$ d for his kind guidance. 


\section{References}

1) Bunting, H., Wis 1 ock i, G. B. and Dempsey, E.W. 1948. The chemical histology of the human eccrine and apocrine sweat glands. Anat. Record, 100: 61-7i.

2) I t o, T. 1949. Histology and cytology of sweat gland (in Japanese). Igakuno-Shimpo, $6: 106-212$.

3) It o, T. and I w a s hige, K. 1953. Zytologische und histologische Untersuchungen über die apokrinen Achselschweissdrüsen von gesunden menschen höheren Alters (in Japanese). Arch. hist. Jap., 5: 455-476.

4) I t o, T., Tsu ch i ya, K. and I w a s h i g e, K. 1951. Studien über die basophile Substanz (Ribonukleinsäure) in den Zellen der menschlichen Schweissdrüsen (in Japanese). Arch. hist. Jap., 2: 279-287.

5) It o, T. and $\mathrm{Ohta}$, T. 1940. A supplemental study on glycogen in the sweat glands (in Japanese). Seitai-no-Kagaku, $1: 146-148$.

6) It o, T. and $\mathrm{Ohta}, \mathrm{T}$. 1950. On the sweat glands in the human nasal wing, especially on the apocrine-like secretion in the socalled eccrine sweat glands (in Japanese). Seitai-no-Kagaku, Vol. 2, No. 1.

7) I washige, K. 1951. Beiträge Zur Kennteis der Eisenreaktion bei den apokrinen Schweissdrüsen der Acheselhaut von Japanern (in Japanese). Arch. hist. Jap., 2: 367-374.

8) K a ga, T. 1956. Cytochemical Studies of Gl. cerminosa in Men and other Mammals. Okajimas Fol. anat. jap., 29: 211-230.

9) Ka mamura, S. 1957. A cytochemical Study of Cat Sweat Glands. Okajimas Fol. anat. jap., $30: 81-92$.

10) Montagna, W. 1956. The structure and function of the skin. Academic Press Inc., New York.

11) Os o g o e, B. 1951. Zytologishe Untersuchung der Gl. ceruminosa (in Japanese). Arch. hist. Jap., 2: 153-173.

12) Taniguchi, T. 1956. Die Schweissdrüse des Menschen und der Saügetiere (mit besonderer Berücksichtigung ihrer quantitativen Verbreitung).

13) Tsukagoshi, N. 1951. Zur Zyotologie der ekkrinen Schweissdrüsen der Tiere mit besonderer Berücksichtigung des Vorkommens der Zwei Arten Drüsen Zellen und ihrer apokrinen Sekretion (in Japanese). Arch. hist. Jap., 2: 481-497.

14) Tsuchiya, K. 1954. A study on the eccrine sweat glands in the human embryo, with special reference to its histo- and cytogenesis. Arch. hist. Jap., 6 : $403-432$.

\section{Explanation of Figures}

\begin{tabular}{lcr} 
Fig. 1. & $\begin{array}{c}\text { Alkaline } \\
\text { phosphatase }\end{array}$ & \multicolumn{1}{c}{ Forehead. } \\
Fig. 2. & -dito- & -dtito- \\
Fig. 3. & -ditto- & Nasal wing. \\
Fig. 4. & -ditto- & -ditto-
\end{tabular}

Apocrine sweat gland.

Eccrine sweat

gland.

Apocrine sweat gland.

Eccrine sweat gland. 
A Cytochemical Investigation on the Sweat Glands of the Monkey

\begin{tabular}{|c|c|c|c|}
\hline Fig. 5. & -ditto- & $\begin{array}{l}\text { Extensor side of the } \\
\text { upper extremity. }\end{array}$ & $\begin{array}{l}\text { Apocrine sweat } \\
\text { gland. }\end{array}$ \\
\hline Fig. 6. & -ditto- & -ditto- & $\begin{array}{l}\text { Eccrine sweat } \\
\text { gland. }\end{array}$ \\
\hline Fig. 7. & -ditto- & $\begin{array}{l}\text { Flexor side of the } \\
\text { upper extremity. }\end{array}$ & $\begin{array}{l}\text { Apocrine sweat } \\
\text { gland. }\end{array}$ \\
\hline Fig. 8. & - ditto- & -ditto- & $\begin{array}{l}\text { Eccrine sweat } \\
\text { g!and. }\end{array}$ \\
\hline Fig. 9. & -ditto- & $\begin{array}{l}\text { Hairy transitional } \\
\text { region of the palm. }\end{array}$ & -ditto- \\
\hline Fig. 10. & -ditto- & Palm. & -ditto- \\
\hline Fig. 11. & Lipase & Forehead. & $\begin{array}{l}\text { Apocrine sweat } \\
\text { gland. }\end{array}$ \\
\hline Fig. 12 . & -ditto- & -ditto- & $\begin{array}{l}\text { Eccrine sweat } \\
\text { gland. }\end{array}$ \\
\hline Fig. 13. & -ditto- & Nasal wing. & $\begin{array}{l}\text { Apocrine sweat } \\
\text { gland. }\end{array}$ \\
\hline Fig. 14. & -ditto- & $\begin{array}{l}\text { Extensor side of the } \\
\text { upper extremity. }\end{array}$ & -ditto- \\
\hline Fig. 15. & -ditto- & -ditto- & $\begin{array}{l}\text { Eccrine sweat } \\
\text { gland. }\end{array}$ \\
\hline Fig. 16. & -ditto- & $\begin{array}{l}\text { Flexor side of the } \\
\text { upper extremity. }\end{array}$ & $\begin{array}{l}\text { Apocrine sweat } \\
\text { gland. }\end{array}$ \\
\hline Fig. 17 & -ditto- & -ditto- & $\begin{array}{l}\text { Eccrine sweat } \\
\text { gland. }\end{array}$ \\
\hline Fig. 18. & -ditto- & $\begin{array}{l}\text { Hairy transitional } \\
\text { region of the palm. }\end{array}$ & -ditto- \\
\hline Fig. 19. & Lipase. & Palm. & $\begin{array}{l}\text { Eccrine sweat } \\
\text { gland. }\end{array}$ \\
\hline Fig. 20. & Glycogen. & Forehead. & $\begin{array}{l}\text { Apocrine sweat } \\
\text { gland. }\end{array}$ \\
\hline Fig. 21. & -ditto- & -ditto- & $\begin{array}{l}\text { Eccrine sweat } \\
\text { gland. }\end{array}$ \\
\hline Fig. 22. & -ditto- & $\begin{array}{l}\text { Extensor side of the } \\
\text { upper extremity. }\end{array}$ & $\begin{array}{l}\text { Apocrine sweat } \\
\text { gland. }\end{array}$ \\
\hline Fig. 23. & -ditto- & -ditto- & $\begin{array}{l}\text { Eccrine sweat } \\
\text { gland. }\end{array}$ \\
\hline Fig. 24. & -ditto- & $\begin{array}{l}\text { Flexor side of the } \\
\text { upper extremity. }\end{array}$ & -ditto- \\
\hline Fig. 25. & -ditto- & $\begin{array}{l}\text { Hairy traositional } \\
\text { region of the palm. }\end{array}$ & -ditto- \\
\hline Fig. 26. & -ditto- & Palm. & -ditto- \\
\hline Fig. 27. & Iron. & Forehead. & $\begin{array}{l}\text { Apocrine sweat } \\
\text { gland. }\end{array}$ \\
\hline Fig. 28 & -ditto- & Nasal wing. & -ditto- \\
\hline Fig. 29. & -ditto- & $\begin{array}{l}\text { Extensor side of the } \\
\text { upper extremity. }\end{array}$ & -ditto- \\
\hline Fig. 30 . & -ditto- & -ditto- & $\begin{array}{l}\text { Eccrine sweat } \\
\text { gland. }\end{array}$ \\
\hline Fig. 31. & -ditto- & $\begin{array}{l}\text { Flexor side of the } \\
\text { upper extremity. }\end{array}$ & $\begin{array}{l}\text { Apocrine sweat } \\
\text { gland. }\end{array}$ \\
\hline
\end{tabular}


Fig. 32.

Fig. 33.

Fig. 34 .

Fig. 35.

Fig. 36.

Fig. 37 .

Fig. 38.

Fig. 39.

Fig. 40.

Fig. 41.

Fig. 42.

Fig. 43.

Fig. 44. -ditto-

-ditto-

-ditto-

-ditto-

Protein.

-ditto-

-ditto-

-ditto-

-ditto-

-ditto-

-ditto-

-ditto-

-ditto- -ditto-

Hairy transitional region of the palm.

$$
\text { -ditto- }
$$

Palm.

Forehead.

$$
\text { -ditto- }
$$

Extensor side of the upper extremity.

$$
\text { -ditto- }
$$

Flexor side of the upper extremity.

$$
\text { -ditto- }
$$

Hairy transitional region of the palm.

$$
\text { -ditto- }
$$

Palm.
Eccrine sweat gland.

Apocrine sweat gland.

Eccrine sweat gland.

-ditto-

Apocrine sweat gland.

Eccrine sweat gland.

Apocrine sweat gland.

Eccrine sweat gland. Excretory duct.

Apocrine sweat gland.

Eccrine sweat gland.

Apocrine sweat gland.

Eccrine sweat gland.

-ditto- 
Plate I

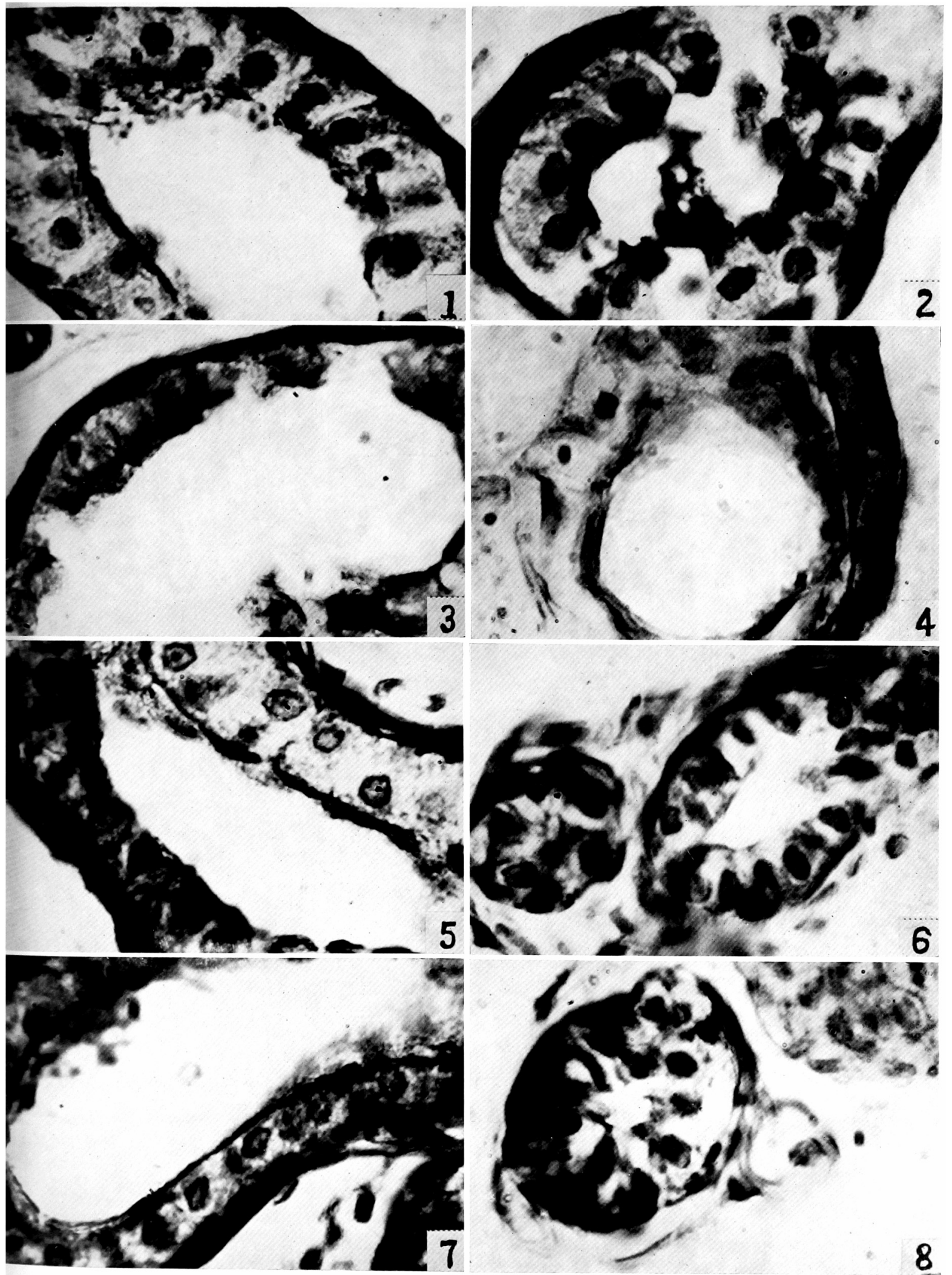

S. Matsumoto, M. Yoshida and U. Tateno 
Plate II
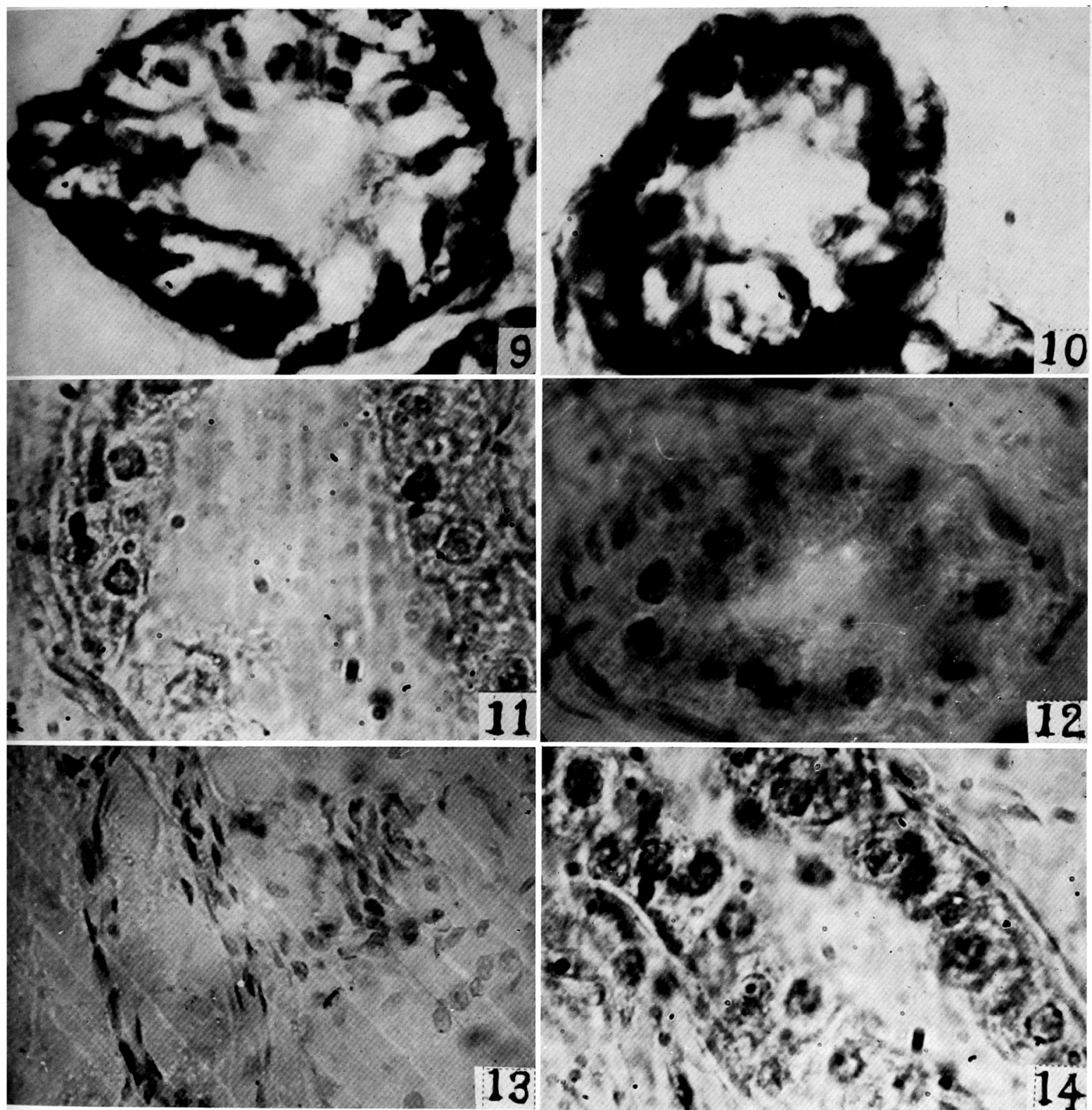

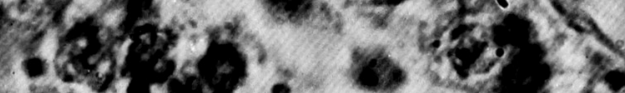
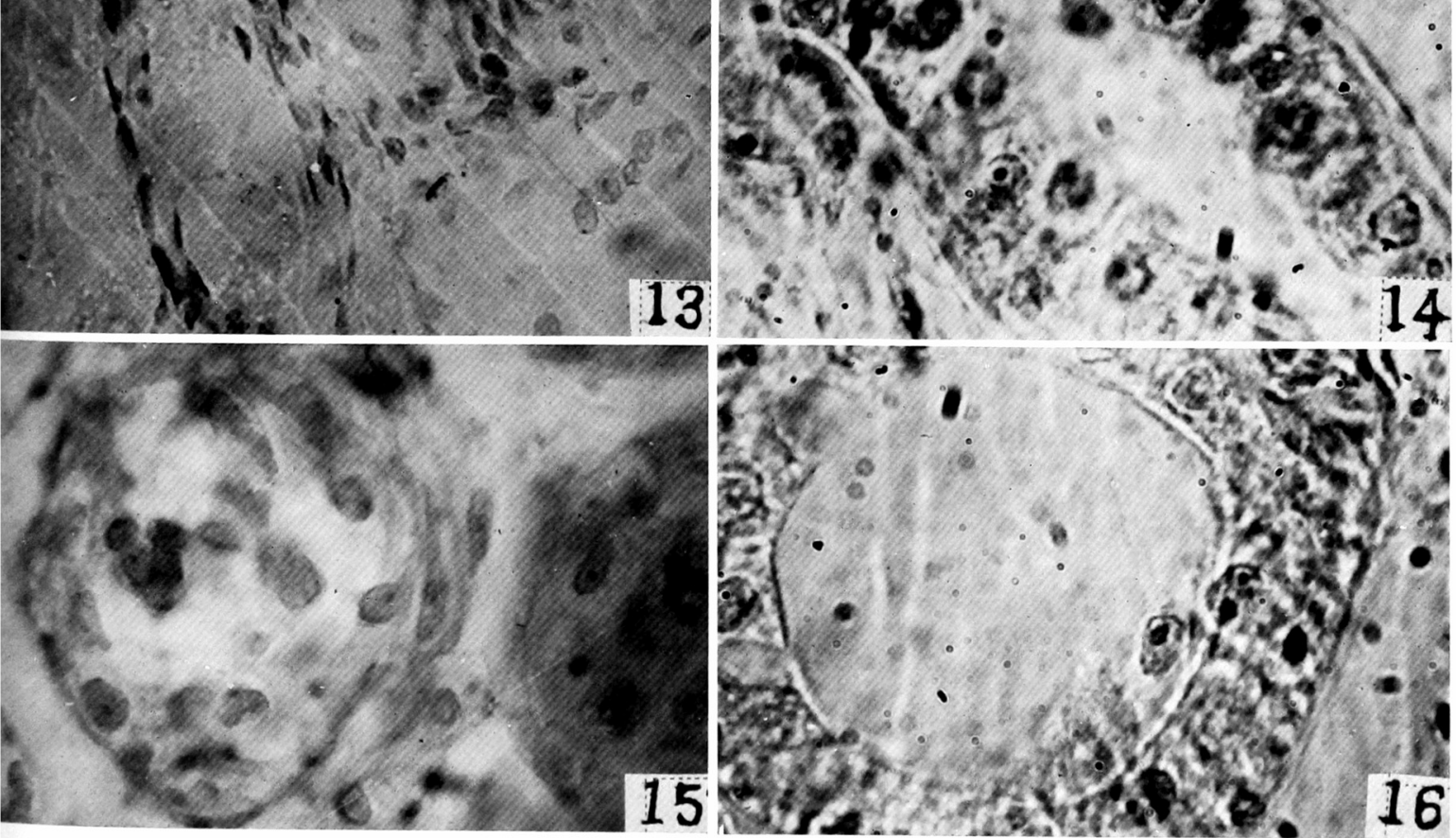

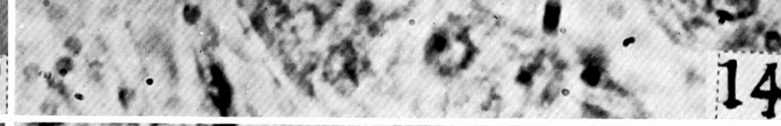

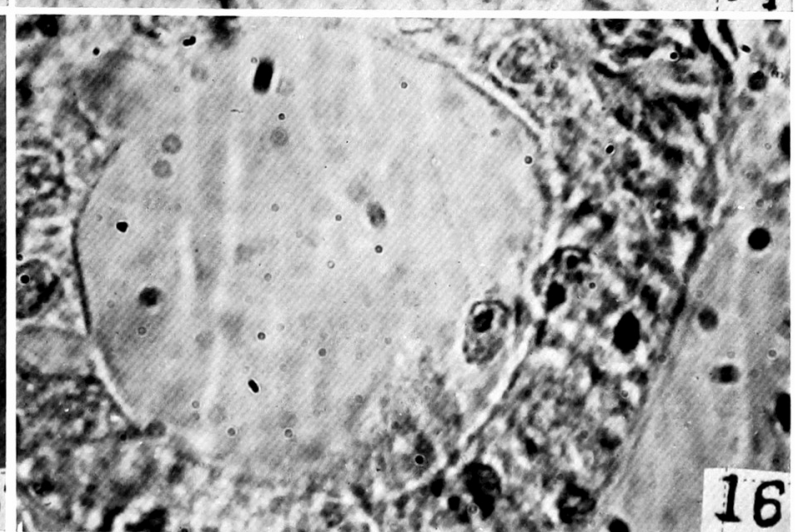

S. Matsumoto, M. Yoshida and U. Tateno 
Plate III

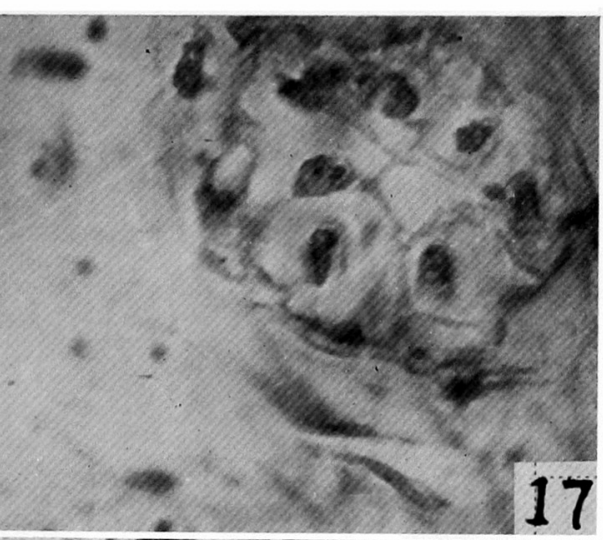

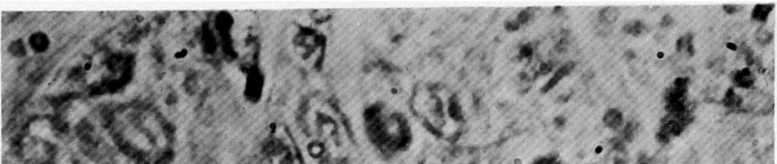

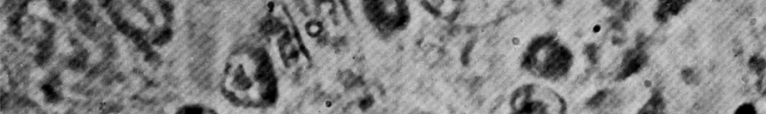

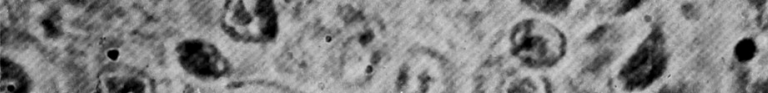

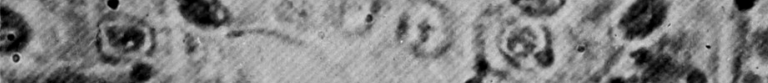

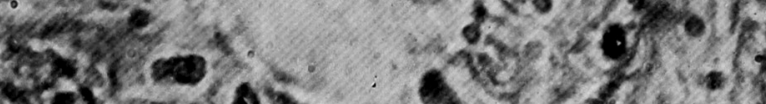

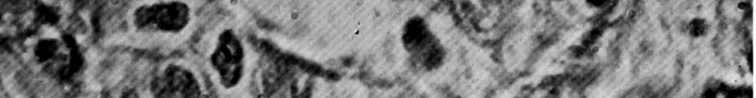
(1)

17

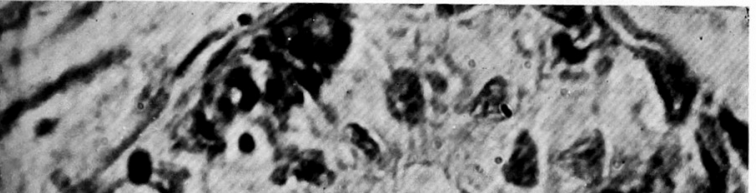

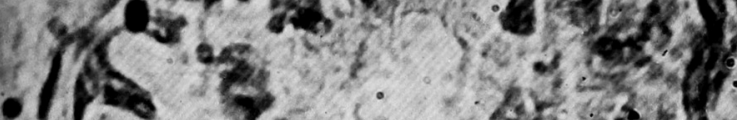

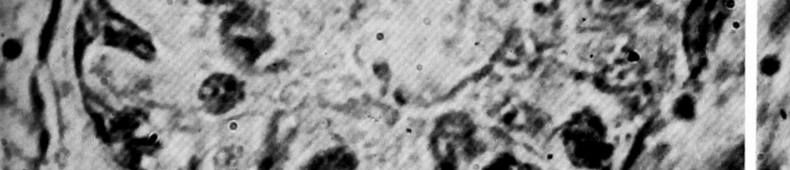

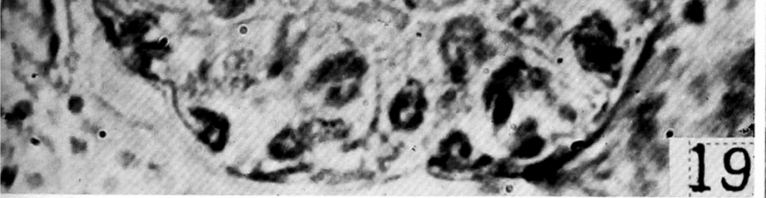
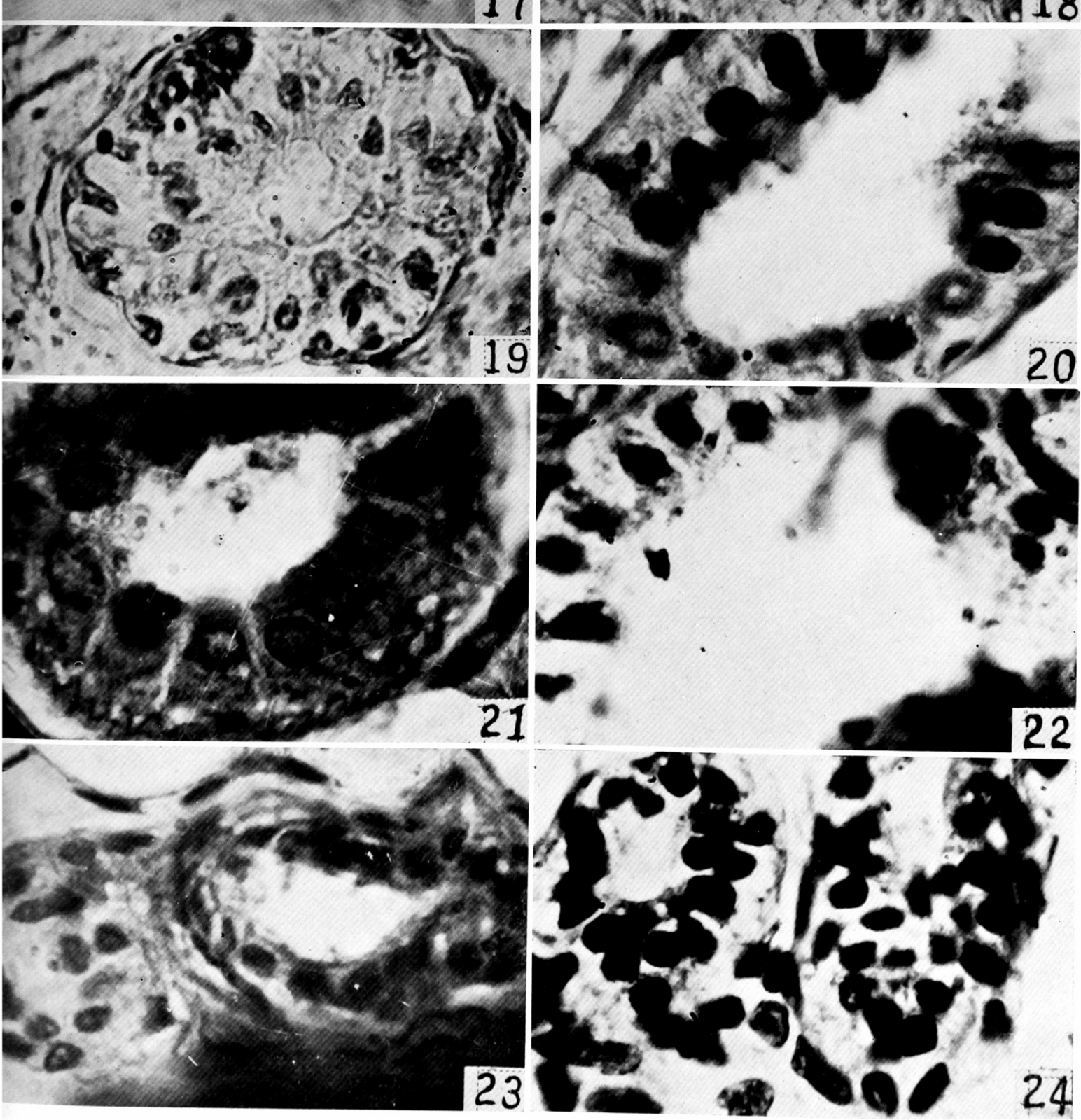

S. Matsumoto, M. Yoshida and U. Tateno

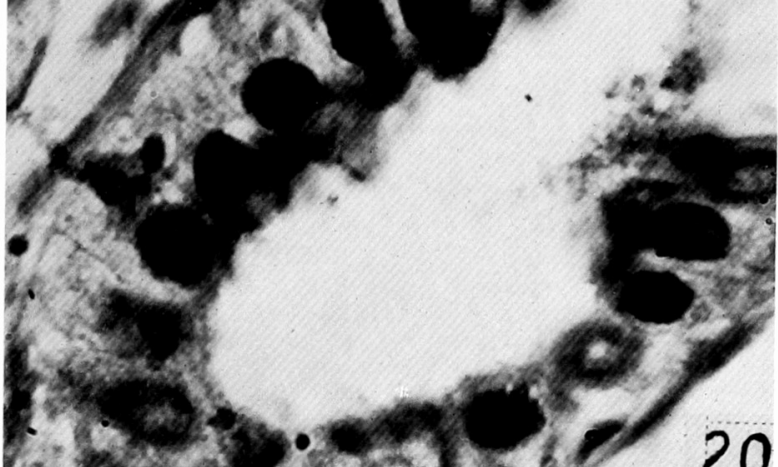


Plate IV

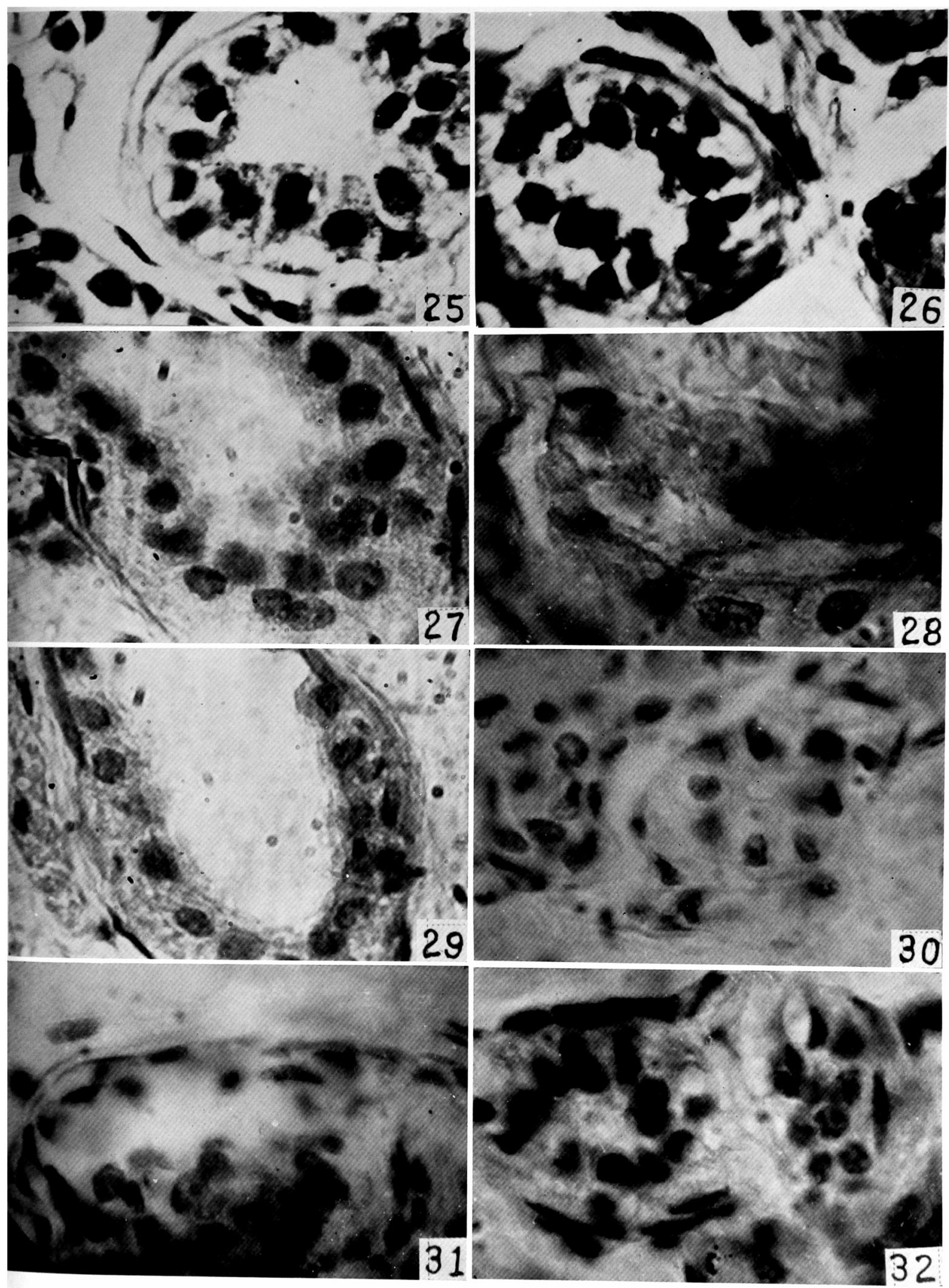

S. Matsumoto, M. Yoshida and U. Tateno 
Plate V

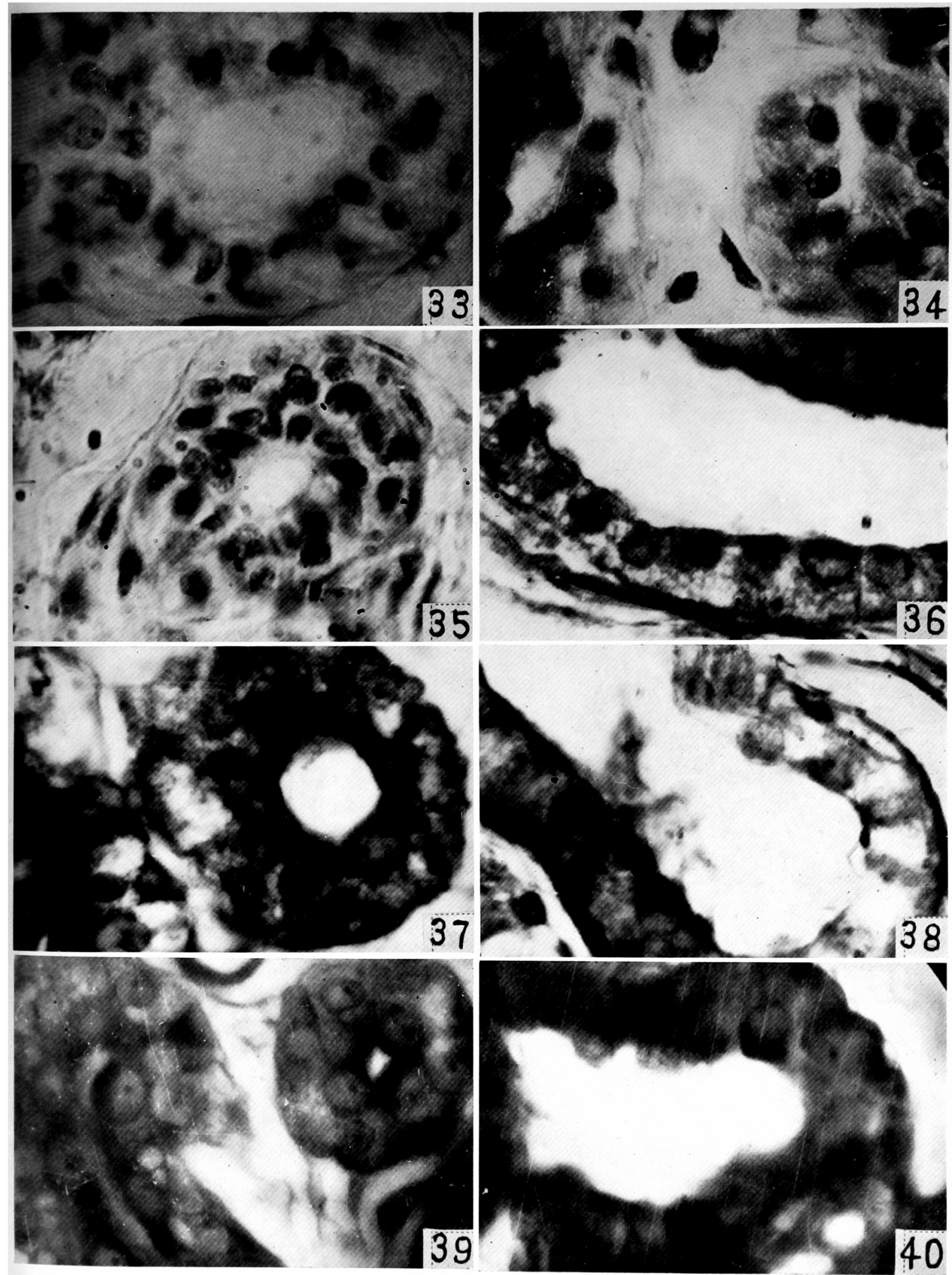

S. Matsumoto, M. Yoshida and U. Tateno 
Plate VI
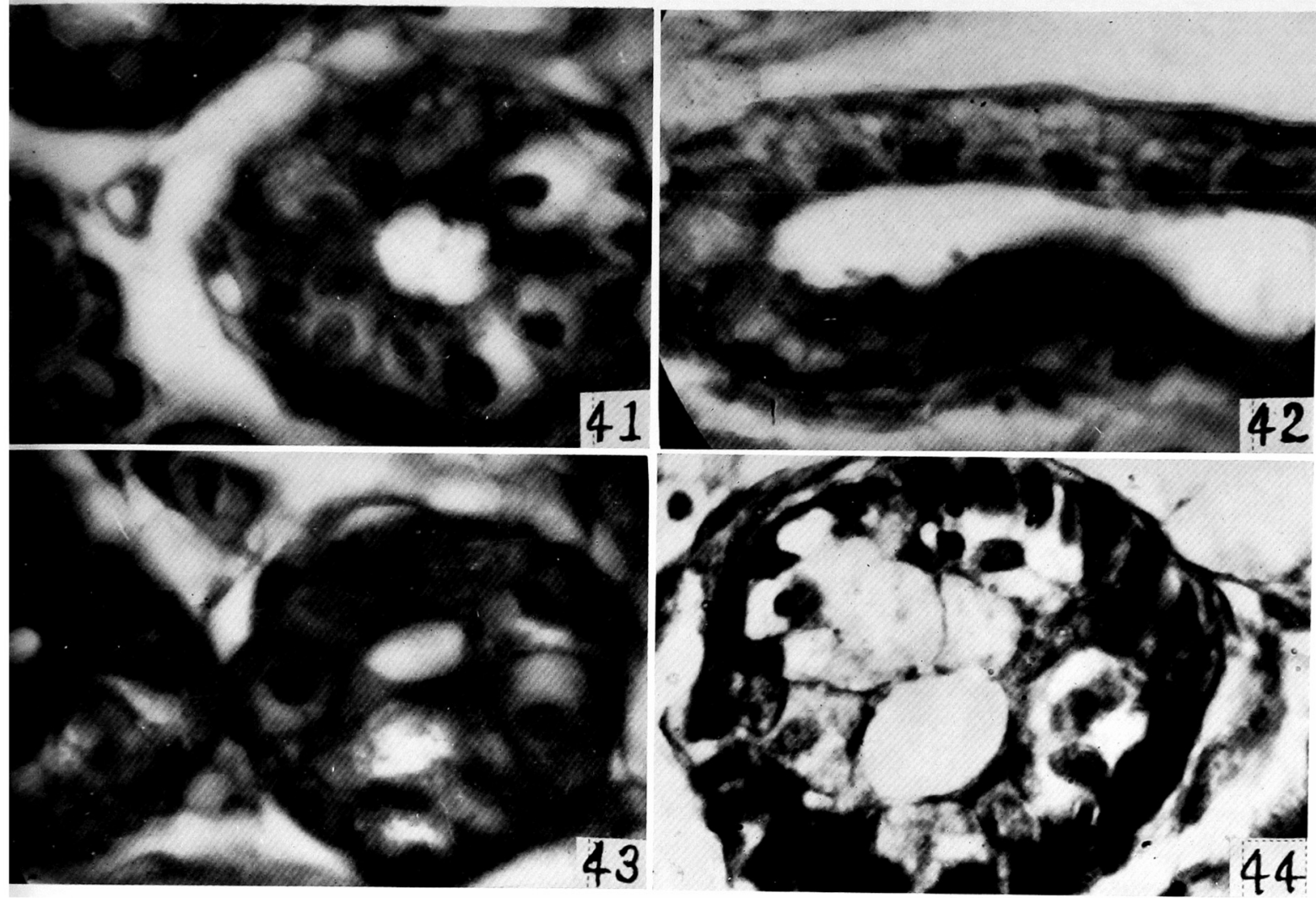

S. Matsumoto, M. Yoshida and U. Tateno 